\title{
Musealized landscapes and petrified landscapes
}

\section{Monika Stobiecka}

(Faculty of "Artes Liberales", University of Warsaw)

ORCID 0000-0003-3774-6159

\begin{abstract}
:
The text aims to reflect upon the notion of landscape in the context of exhibitions; more precisely, it aims to do so in relation to the musealization of archaeological heritage and presentation of archaeology. The last 30 years of museum transformations, referred to as "the age of museums," and the digital shift in museology have had a significant impact on building archaeological narratives in museums and beyond. Immersive and telematic landscapes, currently being constructed in museums, allow for sensorial engagement, broadened perceptive possibilities, and more intense interest in archaeology with the use of complex and convincing visions of the past. Hence, the musealized landscape presented in this paper is to go beyond the traditional criticism of multimedia in museums; it is an attempt to appreciate the cognitive opportunities provided by modern archaeological exhibitions.
\end{abstract}

Key words:

landscape, musealization, archaeological museum, archaeological heritage

\section{Introduction}

"The age of museums" refers to a revolution of sorts and a museum boom that started in the 1990s (Popczyk 2013, 13; MacLeod, Hourston-Hanks, and Hale 2012, XIX). It manifests itself in the significant specialization and variety of museums, their extensive educational and cultural offer, as well as the visible bloom of museum architecture (Chołdzyński 2011; Kalitko 2006; Sirefman 1999; Newhouse 1998). The "museum going trend" (Clair 2007) results primarily from political and economic factors conducive to the protection and development of interest in heritage, as well as from intensified tourism, aestheticization of cities, and theatralization of new exhibition facilities and their surroundings (Popczyk 2013, 13). The museum "coup," as we ought to refer to these deep transformations of the institution over the last 30 years, is the result of critical reflection upon the role of museums that took place 
at the end of the 1980s (Vergo 1989). Since then, traditional exhibitions, associated with dusty showcases, oriented towards visual perception, often intelligible only for experts familiar with their esoteric language, began to function in parallel to the new museum format. Museums and exhibitions opened in the course of the last 20 years are no longer anachronistic mixtures, but rather inviting places of dialogue, contact with culture, and immersion in the past and future. Grand openings of new museums have surely been inspired by the ideas of "The New Museology" (Vergo 1989; Piotrowski 2011), which promote a model of an engaging and participatory exhibition, which oftentimes succeeds by broadening sensory experience during the visit. Engaging audition, touch, smell, or kinesthesia in perception guarantees better memorization, whereby it positively influences the realization of educational goals set by museums. What is more, by renouncing the domination of visual materials, reserved for educated recipients, and incorporating non-visual experiences into the content of exhibitions, new museums turn into institutions that are inclusive, participatory, and as such also democratic (Ziębińska-Witek 2014, 220).

When focusing on new museums and exhibitions, we cannot forget about the role of the digital shift in museology-namely, the introduction of multimedia and modern technologies. A wide range of tools-augmented reality, simulations, fullscale reconstructions and visualizations, and interactive and multimedia exhibits-allows for a full range of sensory experience (Ziębińska-Witek 2015). New technologies dominate most of all in historical and archaeological museums, where the perceptive capacities of the visitors are insufficient for projecting the "invisible and unfathomable" (Květina, Unger, and Vavrečka 2015). Digital supplements of material evidence allow one to experience the past, oftentimes by means of complex reconstruction of objects and characters as well as places and landscapes of the past. Full-scale or digital visualizations of cities, settlements, battlefields, and natural environments can be found in many Polish and foreign museums. Exhibited landscapes are reconstructed so as to cognitively engage as many senses as possible, creating so-called sensescapes (Classen and Howes 2006, 216-19).

In this paper I will analyze musealized landscape based on examples of translations of archaeological heritage into exhibits governed by the rules of museum collections. By musealized landscape I mean full-scale reconstructions, which cognitively engage non-visual faculties and facilitate a reevaluation of thinking about past places, spaces, or habitats. By indicating the role and tasks of modern museums, which guarantee unique experiences, offer sensations, thoughts, and satisfaction impossible to find anywhere else, I would like to stress the positive aspect of reconstructing the past, the possibility of the immersive "going back in time" to a different era and a different place (Kotler and Kotler 1998, 3-5). Hence, I would like to argue against the belief that landscape reconstructed on a museum scale is de facto a static image-a fake, almost prosthetic form of the past, a still life 
(Buchli 2002, 13), an incomplete version of the original that lacks the auratic atmosphere of the past centuries (Ouzman 2006, 274).

\section{Unfamiliar landscape_-Catalonian mines}

Archaeological visualizations created with the use of new technologies such as augmented reality, holographic dioramas, and simulations are currently the leading ways of representing the past in museums, interpretation centers, and archaeological sites. Through visual and attractive depictions of ancient times, new media guarantees access to common cultural heritage, which for a significant part of society seems to be otherwise invisible (Květina 2015). Thereby, modern technologies serving the popularization of archaeology fulfil the postulated democratization of our heritage (Ziębińska-Witek 2014, 17). Traditional methods of presenting archaeology, usually related to displaying the objects of material culture in showcases, are being replaced by new, often impressive and aesthetic forms of representation that engage the audience and provide an immersive experience of the past. They are made possible thanks to telematics-namely, the capacity to technically produce sensory experiences as a result of interacting with multimedia exhibits (Pawleta and Zapłata 2011, 352). Attractive and engaging ways of presenting archaeology in museums operating with new technologies also has significant value in theoretical terms; it encourages the redefinition of past landscapes, objects, and lives. Danuta Minta-Tworzowska notes that crossing the line between virtual reality and the real world changes the sense of archaeology and conjures prehistoric worlds (MintaTworzowska 2011, 326). These reconstructed landscapes of the past consist of fragmentary archaeological remains supported by technological improvements.

The role of simulation and virtual reconstructions in the popularization of archaeology should not be understated, especially in regards to those elements of the past that are unreachable and that often seem to be unbelievable or inconceivable. Thus, the most ancient of times are also the most difficult to comprehend - the vision of the stone age, with its lack of written records, seems incomplete, often intelligible only to a researcher of material culture, and not so to an ordinary recipient. The lack of written records renders the task of reconstructing the past especially challenging. That is why simulations, visualizations, and multimedia representations of the past that facilitate attractive and comprehensible presentations of that specialized knowledge prevail in conveying those esoteric visions of the Paleolithic, Mesolithic, or Neolithic.

The exhibition in Parc Arqueològic Mines de Gavà, located near Barcelona, is a great example of a prehistoric landscape reconstructed and then opened to the public. The exhibition in the Catalonian interpretation center concerns the Neolithic mines found there, once used to extract variscite. To this day the rocky massif overlooks the city, and because of that, spreading the history of the local 
landscape falls within the purview of the institution. A visit to the interpretation center begins with an exhibit that presents vegetation typical for the coastal area in the Neolithic. Then, the visitor enters a dark room where, with the use of multimedia screens, they can participate in "time travel." A simulated explosion and metaphoric return to the stone age creates the impression of diving into the past. Next, the visitor goes into an open, hall-like space containing reconstructions of parts of the mine, which present various aspects related to its operation. There is a multimedia diorama located in the natural environment section-a special exhibit that provides information on the prehistoric landscape. People and animals appear on a static background, which presents vegetation typical for Catalonia. The voice accompanying the diorama talks about the type of landscape, animal species, and human exploitation of the environment. The diorama plays an educational role-it illustrates how the local environment has changed. Numerous comparisons to the modern environment allow the visitor to situate themselves relative to that bygone world.

Archaeological landscape in its musealized form-the multimedia diorama concerning the Neolithic environment along with reconstructed gords, towns, settlements, and caves-not only educates, by bringing cultural heritage closer to society, but it also encourages further reflection upon the role of museums relative to the cultural and environmental reality of the past. In this context, the motivations for creating the interpretation center in Gavà are also important-the willingness to preserve and secure this particular archaeological site and its natural landscape against the elements and intensive tourism, which could spoil this precious rarity. ${ }^{1}$ The small-scale replica of part of the mine, enriched by attractive educational materials, makes this endangered and difficult to imagine landscape available.

\section{Immersive landscape-a walk down the streets of medieval Cracow}

Another approach to archaeological landscape is presented in museums with narration based on material evidence, written sources, and multimedia aids. Rather than playing a compensative role, new technologies are meant to complement the impression of being totally immersed in the past. This complex way of experiencing

\footnotetext{
1 A case of violation and de facto destruction took place in Lascaux cave, which constitutes an emblematic example of an archaeological site from the stone age. The Paleolithic cave from the time of Magdalenian culture (17,000-15,000 BC) was accidentally discovered in 1940. It was almost completely covered in images presenting animals; because of its exceptional archaeological and artistic value, it was added to the UNESCO World Heritage List. The cave was closed to the public in 1963 due to destruction caused by water vapor and carbon dioxide. 20 years later an identical copy was opened just next to the cave; recently it has been enhanced with photogrammetric prints, which accurately recreate the interiors of the precious original. Access to Lascaux II, the ideal copy of the Aquitanian cave, is limited to 2500 visitors a day, which, according to Steven Ouzman, speaks for the great success of the reconstruction and indicates that is has become a monument of equal status to the original, see Ouzman (2006, 271-77).
} 
the past is realized at a permanent exhibition in Cracow's Rynek Underground. Since opening, the exhibition has been very popular among foreign tourist as well as residents of Cracow (Stefanik and Kamel 2013, 13). The main exhibit concerns the center of Cracow in the Middle Ages.

The visit to the underground museum-located in the heart of this historic city, under Sukiennice (the Cracow Cloth Hall) - begins by entering a dark hall through a multimedia curtain. Just like in the Catalonian interpretation center, the visit commences with a rite of passage (Duncan 1995), with time travel. In a narrow corridor that leads to the main display area, there are two videos that convey the bustling atmosphere of the Cracow market-a loud woman encourages buying her products, we can hear hoofbeats and carriages passing by. From the corridor the visitor enters the actual exhibition - an area arranged with the use of archaeological material evidence and multimedia. The whole room is submerged in darkness; the chants of monks, sounds of the bells of the St. Mary's Basilica, and noise from the market come through the speakers. The visitor walks on the original medieval paving, on which stand showcases with relicts and virtual aids. There are also noteworthy largescale reconstructions and spatial arrangements. Cracow workshops and stalls are positioned along paved alleys to ensure a comprehensive experience of a walk around the medieval city. The visitor has an opportunity to get a glimpse of each of the stalls, which renders the experience more realistic. The exhibition also includes a multimedia diorama, which presents some market square buildings burning down; the visitor can stand on the original paving and observe the fire consuming the wooden architecture while listening to the sounds of falling timber. Altogether, the experience of the medieval landscape is influenced by the following components: original material evidence, full-scale arrangements, and realistic sound effects conveying the bustle of the city.

This attractive format, being far from traditional archaeological exhibitions that present showcases with fragmental relicts and unintelligible descriptions, results from a complex approach to the subject. The cultural landscape of medieval Cracow, otherwise inaccessible to modern tourists and residents, becomes tangible, while the interactive, sensorially engaging, and kinesthetic character of the exhibition communicates the atmosphere of the Middle Ages in the former capital of Poland. The experience of the past in the Cracow museum is therefore built with the use of the same epistemic tools that we employ when learning about natural or urban landscape. One's position, listening to the sounds, watching-all of that forms a complete experience of the natural landscape as well as landscapes long past, recreated and musealized. 


\section{Museum landscapes}

The above examples of musealization of archaeological landscapes differ between each other in terms of time frame, location, and presentation. The Catalonian mines, despite their strong presence in the local landscape, are closed to visitors because they could threaten this precious archaeological site. In the case of the center in Gavà, the musealization of the landscape-the relocation of a significant part of cultural heritage, which is present and at the same time unavailable-has a compensatory character. A very different manner of dealing with a bygone landscape was adopted by Rynek Underground in Cracow; it exhibits all that is gone, that is unperceivable in the modern urban tissue, and that constitutes a vital element of the historical identity of the city. Hence, musealization serves to reconstruct that which is inaccessible, made so by the passage of time. Regardless of the glaring differences between these briefly described forms of musealization, they all reconstruct inaccessible cultural heritage and, at the same time, indicate how broadly the museum landscape can be understood.

The great number and variety of museum landscapes-presenting the natural environments of people, urban tissues, the interiors of settlements, and gordssemantically opens the very notion of landscape. What makes this process of semantic acquisition even more dynamic are the relocated elements of heritage that enter modern landscapes and transform them into places of memory (MintaTworzowska 2013). Taking into account the active, sometimes even autopoietic character of musealized landscapes, it is difficult to consider them static, fake, or auraless representations of the past-shortcomings that they are often accused of having. Victor Buchli, in regards to the process of musealization of archaeological heritage, stresses that the sensory experience of artifacts and interaction with the museum exhibits become flattened (Buchli 2002, 13). According to Buchli, archaeological exhibitions are nothing more than still lifes, devoid of the possibility of experiencing the past through sensory involvement (Buchli 2002, 13). Buchli accuses museums of destructive conduct that leads to striping exhibits of their meaningful materiality coming from, among others, their archaeological context. His opinion is deeply rooted in the belief that museums provide a secondary, and therefore artificial, context to the exhibits and that a neutral method of presentation leads to perceiving the artifacts as static and bereft of meaning (SaumarezSmith 1989, 6; cf. Ouzman 2006, 274).

Buchli's conviction concerning the petrification of archaeological objects that takes place in museums seems to be outdated in regards to many modern exhibitions. Engaging and immersive exhibitions, like those described above in Gavà and Cracow, incorporate measures that dynamize the meanings of the past, while the originals and the copies of the artifacts authenticate the experience. Yannis Hamilakis, the author of Archaeology and the Senses: Human Experience, Memory, 
and Affect, notes that material evidence from the past attests to the passage of time and completes the recreated landscapes of memory (Hamilakis 2013, 198). It is usually blended into the exhibition, inconspicuous and uninteresting when contrasted with multimedia exhibits, but its presence, visible signs of the passage of time, and Benjamin's "aura" provide a degree of authenticity to the experience of bygone places. Thus, objects included in complex reconstructions not only prove the accuracy of the vision of the past presented in a museum, but also gain new meanings given to them by curators and visitors. The sensory cognition that accompanies museum landscapes is one of the factors that make visitors subjectify their impressions of the past. Hence, I do not perceive musealization of landscape as petrification, "still life"; on the contrary, the elements that once formed the cultural landscape, now inaccessible and "dead," are dynamized in museums, animated and revived, and thanks to the sensory engagement of the visitors they acquire new meanings. Like Forte, we could even think of musealization as a process that structures and orders the experience of the past. The Italian archaeologist sees in landscape simulation a type of frame for experiencing what is illustrated by a transparent scheme, in which, thanks to the recipient, museum landscape becomes a creative medium with meaning- and culture-forming potential (Forte 2007, 401).

Ideal replicas of cities, gords, and necropolises presented in museums are accused of being illusive and deceptive (Ouzman 2006, 274) by suggesting that the museum vision of the past is always incomplete, crippled, and inferior. At the same time, we forget that the recreated landscapes, regardless of the measures taken in the process of their reconstruction, present that which is completely inaccessible. The possibility of presenting complex structures, surroundings, and environments is of great significance in education. Individual archaeological objects, actuated within multimedia structures, are rendered intelligible, and the vision of the past is made slightly more coherent. Musealized landscapes cannot be considered ideal visions of the past, but rather "shadows" of the past. And just as shadows, they are only a contour, a vague form of the past, but at the same time an active, animated, and engaging one. Neil and Philip Kotler, quoted at the beginning, note that the task of modern museums is to provide visitors with unique experiences-modern exhibition forms, which are immersive and autopoietic, completely realize this task by not only cultivating the memory of bygone landscapes, but also by participating in their subjective redefinition, and enabling unforgettable interactions and experiences.

\section{References:}

Buchli, Victor. 2002. "Introduction." In The Material Culture Reader, edited by Victor Buchli, 1-22. Oxford: Berg.

Brown, Mark. 2016. "Palmyra's Arch of Triumph recreated in Trafalgar Square." The Guardian, April 19. 


\section{Monika Stobiecka}

Chołdzyński, Andrzej M. 2011. "Architektura współczesna i muzea" [Contemporary architecture and museums]. In Ekonomia Muzeum. Materiaty polsko-brytyjskiej konferencji naukowej 25-26 listopada 2010, edited by Dorota Folga-Januszewska and Bartłomiej Gutowski, 67-68. Kraków: Universitas.

Clair, Jean. 2007. Malaise dans les musées. Paris: Flammarion.

Classen, Constance and David Howes. 2006. "The Museum as Sensescape: Western Sensibilities and Indigenous Artifacts." In Sensible Objects: Colonialism, Museums and Material Culture, edited by Chris Gosden, Elisabeth Edwards, and Ruth B. Phillips, 199-222. Oxford: Berg.

Duncan, Carol. 1995. Civilizing Rituals: Inside Public Art Museums. Oxon: Routledge.

Forte, Maurizio. 2007. "Ecological Cybernetics, Virtual Reality, and Virtual Heritage." In Theorizing Digital Cultural Heritage: A critical discourse, edited by Fiona Cameron and Sarah Kenderdine, 389-408. London: The MIT Press.

Forte, Maurizio. 2010. "Introduction to Cyber-Archaeology." In Cyber-Archaeology, edited by Maurizio Forte, 9-13. Oxford: Archaeopress

Forte, Maurizio. 2014. "Virtual Reality, Cyberarchaeology, Teleimmersive Archaeology." In 3D Recording and Modelling in Archaeology and Cultural Heritage: Theory and best practices, edited by Fabio Remondino and Stefano Campana, 113-27. Oxford: Archaeopress.

Hamilakis, Yannis. 2013. Archaeology and the Senses: Human Experience, Memory, and Affect. New York: Cambridge University Press.

Holtorf, Cornelius. 2016. "Why Cultural Heritage is Not 'At Risk' (in Syria or Anywhere)." Heritage for Transformation, April 4. https://heritagefortransformation.wordpress.com/2016/04/04/why-cultural-heritageis-not-at-risk-in-syria-or-anywhere/.

Jalabi, Raya. 2016. "Replica of Syrian arch destroyed by Isis unveiled in New York City." The Guardian, September 20 .

Kalitko, Krzysztof. 2006. "Współczesna architektura muzeów a strategie obecności w przestrzeniach publicznych" [Contemporary museum architecture and the strategies of presence in public spaces]. In Muzeum sztuki. od Luwru do Bilbao, edited by Maria Popczyk, 388-96. Katowice: Universitas

Kotler, Neil and Philip Kotler. 1998. Museum Strategy and Marketing: Designing Missions Building Audiences, Generating Revenues and Resources. San Francisco: Jossey-Bass

Květina, Petr, Jiři Unger, and Petr Vavrečka. 2015. "Presenting the invisible and unfathomable: Virtual museum and augmented reality of the Neolithic site in Bylany, Czech Republic." Archaeologické rozhledy (67): 3-22.

MacLeod Suzanne, Hourston-Hanks Laura, and Jonathan Hale. 2012. "Introduction: Museum Making; The Place of Narrative." In Museum Making: Narratives, Architectures, Exhibitions, edited by Suzanne MacLeod, Laura Hourston-Hanks, and Jonathan Hale, 1-21. New York: Routledge.

Minta-Tworzowska, Danuta. 2011. "Badania nad kulturą wizualną i ich wpływ na konstruowanie obrazów przeszłości przez archeologów" [Research on visual culture and its influence on constructing the image of the past by archaeologists]. In Digitalizacja dziedzictwa archeologicznego. Wybrane zagadnienia, edited by Rafał Zapłata, 315-34. Lublin: Wiedza i Edukacja.

Minta-Tworzowska, Danuta. 2013. "Pamięć 'miejsca pamięci' jako budujące tożsamość w ujęciu archeologicznym" [The Memory of 'places of memory' as constructing identity in an archaeological context]. Przegląd Archeologiczny (61): 33-50. 
Newhouse, Victoria. 1998. Towards a New Museum. New York: The Monacelli Press.

Ouzman, Sven. 2006. "The Beauty of Letting Go: Fragmentary Museums and Archaeologies of Archive." In Sensible Objects: Colonialism, Museums and Material Culture, edited by Chris Gosden, Edwards Elisabeth, and Ruth B. Phillips, 269-301. Oxford: Berg.

Pawleta, Michał and Rafał Zapłata. 2011. "Obrazowanie przeszłości w świetle nowych mediów — technologii cyfrowych" [Imagining the past in light of new media — digital technologies]. In Digitalizacja dziedzictwa archeologicznego. Wybrane zagadnienia, edited by Rafał Zapłata, 335-53. Lublin: Wiedza i Edukacja.

Piotrowski, Piotr. 2011. Muzeum krytyczne [Critical Museum]. Poznań: Rebis.

Popczyk, Maria. 2013. "Autonomia ekspozycji muzealnej" [The Autonomy of museum exhibition]. In Muzeum a zabytek. Konflikt czy harmonia? Materialy z konferencji naukowej w MN w Krakowie 31 marca - 2 kwietnia 2011, edited by Krystyna Stefaniak, 12-21. Kraków: Muzeum Narodowe.

Saumarez-Smith, Charles. 1989. "Museums, Artefacts, and Meanings." In The New Museology, edited by Peter Vergo, 6-21. London: Reaktion Books.

Sirefman, Susan. 1999. "Formed and Forming: Contemporary Museum Architecture." Daedalus (3): 297-320

Solli, Brit, Burström Mats, Domanska Ewa, Edgeworth Matthew, González-Ruibal Alfredo, Holtorf Cornelius, Lucas Gavin, Oestigaard Terje, Smith Laurajane, and Christopher Witmore. 2011. "Some Reflections on Heritage and Archaeology in the Anthropocene Heritage and Archaeology in the Anthropocene." Norwegian Archaeological Review 1 (44): 40-88.

Stanco, Filippo, Tanasi Davide, Allegra Dario, Milotta Filippo L.M., Lamagna Gioconda, and Giuseppina Monterosso. 2017. "Virtual Anastylosis of Greek Sculpture as Museum Policy for Public Outreach and Cognitive Accessibility." Journal of Electronic Imaging 26 (1): 1-12.

Stefanik, Magdalena and Marta Kamel. 2013. "Muzea i wystawy interaktywne w Polsce — współczesna atrakcja turystyczna" [Interactive museums and exhibitions in Poland — contemporary touristic attraction]. Turystyka kulturowa 8: 5-24.

Vergo, Peter, ed. 1989. The New Museology. London: Reaktion Books.

Ziębińska-Witek, Anna. 2014. "Renesans materialności, czyli o powrót obiektów do muzeum" ["The Material renaissance or about the return of objects to museums"]. In Historia — dziś. Teoretyczne problemy wiedzy o przeszłości, edited by Ewa Domańska, Rafał Stobiecki, and Tomasz Wiślicz, 217-28. Kraków: Universitas.

Ziębińska-Witek, Anna. 2015. "Muzea wobec nowych trendów w humanistyce. Refleksje teoretyczne" [Museums and new trends in the humanities: Theoretical reflections]. Historyka. Studia metodologiczne 45: 97-115. 